The second item is Crick (Thorne), Sketches from the Diary of a Commercial Traveller, published in London, 1847, by Joseph Masters on Aldersgate Street. That there is little difference between the ancient and modern salesman may be found in the following comment: "A Commercial man who discharges his duty conscientiously has, indeed, little time for aught but business; and although a playfulness of disposition may be produced by his bustling, healthy occupation, and an external appearance of cheerfulness may characterize his proceedings, he will unfortunately while bearing a smile on his brow, have corroding cares within." Among the subjects discussed are Necessity of Keeping the Commercial Room Select, The Miseries of Casual Horse-Hiring, Necessity and Advantage of Life Assurance, Inconveniences at Railway Stations, A Bar-Maid's Idea of the Average Commercial Traveller, and the Ethics of the "Profession."

\title{
Library Gifts
}

A FulL record of the gifts constantly flowing in to The Business Historical Society and the Harvard Business Library would require more space than we have, at present, at our disposal. Last year there were over three thousand. The following list will indicate the kind and amount of material which is constantly being sent in.

Charles H. Taylor, Manager, Boston Globe, Boston, Mass.

R. L. Smitley, Dixie Book Shop, New York.

Farmers Loan \& Trust Company, New York City.

I4 cases of state banking reports and miscellaneous material.

Stone $\&$ Webster, Boston, Mass. Mr. George W. Lee, Librarian.

9 cases of miscellaneous material, such as annual reports, mortgages, etc.

Massachusetts State Library, Boston. Mr. Edward H. Redstone, Librarian.

30 cases, including volumes of New York City Record, foreign labor material, etc.

Lee, Higginson \& Company, Boston, Mass.

$I_{4}$ boxes of annual reports and other material.

Kidder, Peabody \& Company, Boston. Mr. Robert Storer.

I 6 boxes of various annual reports and miscellaneous material.

Hornblower \& Weeks, Boston, Mass.

5 cases of miscellaneous material. 
White, Weld \& Company, New York City.

5 boxes of corporation reports.

Guaranty Trust Company of New York, New York City.

4 boxes of miscellaneous material.

Old Colony Trust Company, Boston, Mass.

8 cases directories, manuals, Chronicles, etc.

First National Bank of Boston, Boston, Mass.

2 cases of directories, annual reports, etc.

New London Public Library, Connecticut. Frederick W. Edgerton, Librarian.

69 cases of government documents.

Mr. Robert Storer, 2 Fair Oaks Park, Needham, Mass.

Various collections of material, including state insurance reports, Farmers' Almanacs, and miscellaneous books and pamphlets.

Standard Statistics Company, New York City. Miss Eleanor Cavanaugh, Librarian.

About five hundred volumes of state reports and court records on important business cases.

Remick, Hodges \& Company, New York City.

2 cases of indentures.

Miss Clara Bennett, 199 Main Street, F-airhaven, Mass.

Account book and Ledger book of Mr. Humphrey Howland dating from about 1780 to I 805 ; and also a copy of Rowlett's Tables of Discount or Interest - printed in Philadelphia, 1833.

Hamilton Manufacturing Company, Lowell, Mass. Mr. F. C. Dumaine, Jr., Treasurer.

50 boxes of miscellaneous account books and papers dating approximately from 1825 to 1900 .

Mr. John C. Phillips, Wenham, Mass.

Business letters, papers and ledgers.

Massachusetts Institute of Technology, Cambridge, Mass. Professor Davis R. Dewey.

2 cases of annual reports of railroads, industrial and public utility companies.

Miss Edith M. Howes, 59 Pleasant Street, Brookline, Mass.

An autobiographical sketch of Osborn Howes, edited by his children, Boston, I 894 .

Irving Bank Columbia Trust Company, New York City. Mr. Walter E. Lagerquist.

One box of corporation reports.

Mr. Charles I. Grames, 8 Holyoke Street, Cambridge, Mass.

A ledger book, I 786 , of the Rainsford family.

Mr. A. D. Wilt, Sr., New Canaan, Conn.

3 boxes of miscellaneous books. 
Bowdoin College Library, Brunswick, Maine. Mr. G. G. Wilder, Librarian. One box of books, including seven volumes of Anderson \& MacPherson's historical works on business.

Mrs. George B. Glidden, I673 Beacon St., Brookline, Mass.

A collection of newspapers printed in Boston, 1742-45.

Dillon, Read \& Company, Boston, Mass.

I4 cases of library material, including Poor and Moody Manuals, Chronicles, etc.

Miss Emily Hussey, I Irving Street, New Bedford, Mass.

Copies of Farmers' Almanac and copies of Liverpool Review about I 850 ,

Connecticut State Library, Hartford, Conn. Mr. George S. Godard. State Librarian.

A set of Connecticut Public Documents for over thirty years.

Mr. J. Cooke, II, Charles D. Barney \& Company, Philadelphia, Pa,

Records and papers of Jay Cooke and his adventures with the Northern Pacific Railroad.

Boston News Bureau, Boston, Mass. Mr. Guy Bancroft.

6 boxes of scrapbooks.

Mr. George Woodbridge, I3 I State Street, Boston, Mass.

Miscellaneous books.

Jackson \& Curtis, Boston, Mass.

Commercial and Financial Chronicles, Poor's Railroad Manuals, etc.

Mr. Edward A. Woods, Manager, E. A. Woods Company, Pittsburgh, Pa.

Pennsylvania Insurance Reports and other publications on insurance.

Mrs. Charles D. Norton, 635 Park Avenue, New York City.

4 boxes of business books.

U. S. Geological Survey, Department of the Interior. Miss Julia L. V. McCord, Librarian.

6 boxes of various books and pamphlets.

Mr. George O. Smith, Director of U. S. Department of the Interior, Geological Survey, Washington, D. C.

Collection of printed briefs and statements submitted to U. S. Coal Commission.

New England Mutual Life Insurance Company, Boston, Mass.

Miscellaneous insurance material.

Mr. Grafton D. Cushing, 7 I 9 Barristers Hall, Pemberton Square, Boston.

Account books, I $835-45$.

Mrs. Sarah W. Hallowell, 8o Mystic Street, West Medford, Mass.

Reports of the U. S. National Monetary Commission.

Mr. A. M. Day, Wood, Struthers \& Company, 5 Nassau Street, New York.

8 boxes miscellaneous material including Reports of the Secretary of the Treasury, volumes of Political Science Quarterly, etc.

Mr. Stuyvesant Fish, 37 Wall Street, New York City.

Collection of annual reports and various financial volumes. 